\title{
The Impact of Covid-19 Pandemic on Taxpayers' Compliance of MSMEs in Palembang
}

\author{
Noviyanti $^{1 *}$, S. M. Ferdous Azam ${ }^{2}$ \\ ${ }^{1,2}$ Department of Graduate School of Management, Management \& Science University, \\ 40100 Selangor, Malaysia. \\ Noviysc@gmail.com (Noviyanti),+62 82175158552 \\ drferdous@msu.edu.my (S. M. Ferdous Azam), +60 166831785
}

Received 26 February 2020, Revised 4 March 2021, Accepted 29 March 2021

\begin{abstract}
This study aims to determine the impact of the attitude of taxpayers, taxpayers' knowledge, taxpayers' awareness, and tax socialization on taxpayers' compliance of Micro, Small, Medium-sized Enterprises (MSMEs) in Palembang, Indonesia during the Covid-19 Pandemic. A quantitative research method is used with a deductive research approach. This study used primary data by distributing questionnaires to taxpayers' compliance of MSMEs in Palembang, Indonesia. The sample size used was 396 respondents with a total population of 37.902 (Department of Cooperatives and MSMEs, 2019) by using simple random sampling. Moreover, the IBM SPSS 20 software is used for analytical tool in this study. The results of this study indicate that partially the attitude of taxpayers', taxpayers' knowledge, and taxpayers' awareness have a positive and significant effect on taxpayers' compliance. On the other hand, tax socialization has no effect on taxpayers' compliance.
\end{abstract}

Keywords: Attitude of taxpayers, Taxpayers' knowledge, Taxpayers' awareness, Tax socialization, Taxpayers' compliance

\section{INTRODUCTION}

The most important source of funds in each country's revenue is taxes. Taxes are used to fund government spending as well as state development. The main problem regarding taxes in Indonesia is regarding the compliance of taxpayers to report and submit their tax payable, therefore the reporting and submission of tax obligations in Indonesia are still quite low (Directorate General of Taxes 2020, 2020). Taxpayer compliance in carrying out its tax obligations is a very important issue in Indonesia because taxpayers who do not comply with their tax obligations will harm the state, namely reduced state cash revenue (Dodik et al., 2020). In addition to taxpayers' compliance, tax avoidance actions carried out by taxpayers also always make state cash receipts do not reach the target every year (Noviyanti \& Ferdous, 2020), therefore tax knowledge and socialization from the tax directorate general is still needed. This is because the majority of MSMEs in Indonesia is considered not fully familiar with taxes and only a few MSME actors understand that they are taxpayers who have to pay taxes and take advantage of tax incentives from the government in certain situations (Pramandari et al., 2018).

Also, since the Covid-19 pandemic came to Indonesia, the business sector that has felt the most impact from Covid-19 is micro, small, and medium enterprises (MSMEs) (Rosita, 2020). The entire of MSMEs especially in Palembang city, both small and large scale, have experienced a decline in turnover and some have not even received any income since the Covid-19 pandemic (Department of Cooperatives and MSMEs, 2019). Covid-19 or what is known as the coronavirus is an infectious disease caused by the acute respiratory syndrome coronavirus2 (severe acute respiratory syndrome coronavirus 2 or SARScoV-2). Coronavirus causes respiratory infections, such as flu, MERS (Middle East Respiratory Syndrome), and SARS (Severe Acute Respiratory Syndrome). This coronavirus was first discovered in Wuhan, Hubei, China in 2019 (Ilmiyah, 2020), (Hui, D. S., E. et al., 2020). Many researchers also have contributed in many sectors on preventing and detecting the diffusion of Covid-19 that implemented in many advanced technologies like thermal screening (Yusuf et al., 2020) based on drones (Mohammed et al., 2020) and smart glasses (Mohammed et al., 2020) as well as a smart helmet (Mohammed et al., 2020) that using IoT to enhance the performance of process monitoring.

The Covid-19 pandemic has changed many aspects of human life. The consequences of the Covid19 pandemic are not only visible in the health aspect of mankind (Laraswati, 2020), but also in the economic aspect. In the midst of the coronavirus 
pandemic and the existence of the Large-Scale Social Restriction policy in Indonesia, many MSMEs have drastically decreased their turnover and complained of difficulties in paying taxes (Rosita, 2020). Not only in Indonesia but (Koshle \& Kaur, 2020) also examined the impact of the Coronavirus on businesses in India which caused losses of not less than USD 348 million due to the economic slowdown and policy consequences. Moreover, the World Bank predicts that around 11 million people in the East Asia and Pacific region experience poverty, while the World Trade Organization recorded a decrease in international trade in the first quarter of 2020 by $13 \%$ to $32 \%$ (Marsudi \& P, 2020).

In the results of a survey by the United Nations Development Program (UNDP) with LPEM FEB UI. As many as $77 \%$ of MSME players stated that their income had decreased due to the corona pandemic. Only $7 \%$ of MSME actors admitted that their income had increased due to the pandemic. Then, 3\% of MSME actors stated that their income did not change during the pandemic. As many as $6 \%$ of MSME actors admit that they do not know about changes in income. Meanwhile, the remaining $7 \%$ think it is too early to declare a change in income due to the pandemic (Bayu, 2021). With a lot of reduced income due to the Covid-19 pandemic, not many MSME taxpayers have to carry out their obligations as taxpayers in reporting taxes. This can be caused by a lack of good attitude and lack of knowledge from taxpayers, taxpayer awareness, and tax socialization from the tax directorate general of taxpayer compliance in tax reporting (Perdana \& Dwirandra, 2020).

Taxpayers' compliance can be influenced by several factors, such as taxpayers' awareness and taxpayers' knowledge. The results of previous research conducted by Perdana \& Dwirandra (2020), Cahyani \& Noviari (2019), Adnyana \& Jati (2018), A. P. Sari \& Wirakusuma (2018), and Budhiartama \& Jati (2016) show that taxpayers' knowledge and taxpayers' awareness have a positive and significant effect on taxpayers' compliance. While research conducted by Markhumah (2019), Sentanu \& Setiawan (2016), and Nugroho et al., (2016) show that taxpayers' awareness and taxpayers' knowledge have no effect on taxpayer compliance. Research conducted by Yustikasari et al., (2020) has different results, namely that taxpayers' awareness has no effect on taxpayers' compliance, but taxpayers' knowledge influences on taxpayers' compliance.

Not only taxpayers' awareness and taxpayers' knowledge, but taxpayers' compliance is also influenced by the attitude of taxpayers and tax socialization. The results of previous research conducted by Yustikasari et al., (2020), Aruan et al., (2017), Mintje (2016) and Budhiartama \& Jati (2016) indicate that taxpayers' attitudes have an influence on taxpayer compliance. On the other hand, I. K. Sari \& Saryadi (2019), Boediono et al., (2018), Hafiz \& Saryadi (2018), Wardani \& Wati (2018) and Lubis
(2017) state that tax socialization affects taxpayers' compliance. Meanwhile Setyaningrum (2017) and Winerungan (2013) revealed that taxation socialization had no effect on taxpayer compliance as well as Wijaya \& Sari (2019) stated that taxpayer attitudes and taxation socialization had no effect on taxpayer compliance and also Dewi \& Putra (2019) who stated that the attitude of the taxpayer has no effect on the taxpayer's compliance. Based on the above issues, therefore the objectives of this research are to determine the impact of Covid-19 Pandemic on taxpayers' compliance of MSMEs in Palembang, Indonesia.

\section{LITERATURE REVIEW}

There are two theories that support this research, namely compliance theory and the theory of planned behavior. Compliance theory is a theory that explains a condition in which a person obeys the orders or regulations given (Handke \& Barthauer, 2019). Meanwhile, the Theory of Planned Behavior is a person's intention to behave (Ajzen, 2005). A person's intention is determined by behavior belief, normative belief, and control belief (Sulistiyani \& Harwiki, 2016) and (Ghouri et al., 2016).

\section{Attitude of Taxpayers'}

Yustikasari et al., (2020) give an overview that the attitude of taxpayers is the existing view of a taxpayer, which provides or does not provide benefits related to objects, people or events. Besides, the taxpayer's attitude is a taxpayer's consideration of the advantages and disadvantages of fulfilling their tax obligations, consideration of financial conditions to meet tax obligations and the risks that will arise from not paying taxes (Susyanti \& Anwar, 2020). On the other hand, Utami \& Kardinal (2012) state that the attitude of the taxpayer determines the actions or decisions taken by taxpayers both through services and through what taxpayers feel and experience. Meanwhile, Utomo (2011) gives an overview that the attitude of the taxpayer can be interpreted as a statement, the individual considerations of the taxpayer which are the basis of interactions with other people or events, whether beneficial or unfavorable regarding an object.

\section{Taxpayers' Knowledge}

Based on the Theory of Planned Behavior, taxpayers' knowledge is related to normative beliefs which are the perceived expectations of one or more people to agree on a behavior and motivate someone to comply with their obligations. Concerning compliance theory, adequate tax knowledge will make it easier for taxpayers to fulfill their tax obligations. An important element in the voluntary tax system is knowledge of taxation (Dodik et al., 2020). Besides, Brainyyah (2013) gives an overview that Taxpayers' knowledge is all information related to taxation that is used to act, make conclusions, and to develop certain 
strategies that lead to fulfilling payment rights and tax obligations. Moreover, Tax Knowledge is a step towards maturing a taxpayer's thinking through teaching and training efforts (Hardiningsih \& Yulianawati, 2011).

\section{Taxpayers' Awareness}

Based on Theory of Planned Behavior, Taxpayers' awareness is related to behavior belief which explains that individual attitudes will influence individual desires to act by knowing the results of the actions taken by the individual (Ghouri et al., 2016). Concerning compliance theory, high taxpayer awareness will affect the level of compliance where the more taxpayers are aware, the level of compliance will increase. Consciousness is where every human element understands reality and how to react or respond to reality (Kamil, 2015). Taxpayer awareness and compliance is a condition in which taxpayers know, understand, and carry out their tax obligations properly and voluntarily (Wahyudi \& Intrada, 2019).

\section{Tax Socialization}

Christiani (2016) states that tax dissemination is an effort made by the Directorate General of Taxes through its officials to provide understanding, information and guidance to the public in general and taxpayers in particular, regarding everything related to taxation legislation. Socialization is an effort made by the Director General of Taxes through various methods to provide information related to all regulations and activities related to taxation so that it can be implemented by the public in general, especially taxpayers, both individuals and business entities (Faizin, M. R. \& Ruhana, 2016). In addition, Sudrajat \& Ompusunggu., (2015) gives an overview that socialization of taxation means an effort made to provide information about taxation which aims to make a person or group understand about taxation so that taxpayer compliance will increase.

\section{Taxpayers' Compliance}

According to Susyanti \& Anwar (2020), taxpayers' compliance is an act of taxpayers in fulfilling their tax obligations following the provisions of laws and regulations and tax implementation regulations in force in a country. While Ermawati (2018) and Sufiah (2017) state that taxpayers who pay and report taxes on time are called taxpayer compliance. With the compliance of taxpayers, it is hoped that taxpayers will try to comply with the applicable tax laws, either fulfilling their obligations or exercising their tax rights (Widowati, 2015). Moreover, Widagsono (2017) and Subekti (2016) give an overview that taxpayer compliance is the attitude that taxpayers have in carrying out their tax obligations accordingly without being forced.

\section{Conceptual Framework}

This conceptual framework describes the relationship between the dependent variable and the independent variable as well $^{\mathrm{H}}$ as provides an overview of the framework that ${ }_{\mathrm{H}_{4}}^{\mathrm{H}_{3}}$ will be created in the hypothesis. This below is an example of a conceptual framework in this study:

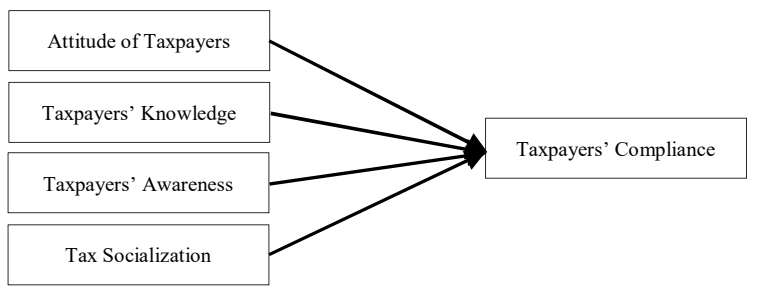

Figure 1: Conceptual Framework

Based on the literature review and conceptual framework, the following hypotheses can be drawn:

H1: Attitude of taxpayers have an influence on taxpayers' compliance during the Covid-19

H2: Taxpayers' knowledge has an influence on taxpayers' compliance during the Covid-19

H3: Taxpayers' awareness has an influence on taxpayers' compliance during the Covid-19

H4: Tax Socialization has an influence on taxpayers' compliance during the Covid-19

\section{METHODS}

The object of this study is the attitude of taxpayers, taxpayers' knowledge, taxpayers' awareness, and tax socialization on taxpayers' compliance. The research method used is the quantitative method. The data used in this study is primary data, namely the results of a questionnaire distributed to MSMEs in Palembang, Indonesia. The population of MSMEs in Palembang, Indonesia is at 37.902 (Department of Cooperatives and MSMEs, 2019). The number of samples is determined using the Slovin formula with the error rate used is $5 \%$ and the confidence level of the sample in the population is $95 \%$. Based on calculations on the Slovin formula, the sample results were 396 MSMEs in Palembang, Indonesia. The sampling technique used is probability sampling with simple random sampling. The analytical method in this study used reliability analysis, Pearson correlation analysis, determination coefficient test $\left(\mathrm{R}^{2}\right)$, and hypothesis testing.

\section{RESULTS AND DISCUSSION}

This part gives an overview the results of the statistical analysis by using IBM SPSS version 20 which consists of reliability analysis, pearson correlation analysis, determination coefficient test $\left(\mathrm{R}^{2}\right)$, hypothesis testing which consists of the F-test and t-test. 


\section{Reliability Analysis}

The purpose of reliability analysis is to find out whether the results of Cronbach's alpha on each variable are reliable or not. Variables will be said to be reliable if the results of Cronbach's alpha is more than 0.7 and not reliable if Cronbach's alpha is less than 0.7 (Sekaran \& Bougie, 2016).

Table 1

Reliability Analysis

\begin{tabular}{lcccc}
\hline \multirow{2}{*}{ Variables } & \multicolumn{2}{c}{ Pilot Study } & \multicolumn{2}{c}{ Actual Data } \\
\cline { 2 - 5 } & $\mathrm{N}$ of Items & Cronbach's Alpha & N of Items & Cronbach's Alpha \\
\hline Attitude of taxpayers & 7 & 0.838 & 7 & 0.845 \\
\hline Taxpayers' knowledge & 7 & 0.871 & 7 & 0.836 \\
\hline Taxpayers' awareness & 7 & 0.965 & 7 & 0.925 \\
\hline Tax socialization & 7 & 0.836 & 7 & 0.855 \\
\hline Taxpayers' compliance & 7 & 0.852 & 7 & 0.863 \\
\hline
\end{tabular}

In the case processing summary table, the amount of valid data to be processed and issued data is 396 with a percentage of $100 \%$ and no data is issued or excluded with a total of 482 data. This output is used as a result of the reliability analysis using the Cronbach's Alpha technique used to determine whether an instrument is reliable or not by using an Alpha value limit of 0.7 . In the output above, both Cronbach's Alpha value for the entire variables in pilot study and actual data are above 0.7 . Therefore, this instrument has been reliable. According to (Kline, 2011), to find out whether the data is normally distributed or not, the criteria used are if the skewness ratio is between +3 to -3 and the criteria used are if the kurtosis ratio is less than 10 , then the data distribution is normal. In this study, the data is normally distributed.

\section{Pearson Correlation Analysis}

The symbol for Pearson correlation is " $\rho$ " when measured in population and " $r$ " when measured in a sample. Because this will deal with almost exclusively sample, this will be users to represent pearson correlations unless stated otherwise. Pearson $r$ can range from -1 to 1 . $\mathrm{r}$ from -1 indicates a perfect negative linear relationship between variables, $\mathrm{r} 0$ indicates there is no linear relationship between variables, and $r$ of 1 shows a perfectly positive linear relationship between variables.

Table 2

Pearson Correlation Analysis

\begin{tabular}{|c|c|c|c|c|c|c|}
\hline & & $\begin{array}{l}\text { Attitude of } \\
\text { taxpayers' }\end{array}$ & $\begin{array}{l}\text { Taxpayers' } \\
\text { knowledge }\end{array}$ & $\begin{array}{l}\text { Taxpayers' } \\
\text { awareness }\end{array}$ & $\begin{array}{c}\text { Tax } \\
\text { socialization } \\
\end{array}$ & $\begin{array}{l}\text { Taxpayers' } \\
\text { compliance }\end{array}$ \\
\hline Attitude of taxpayers' & $\begin{array}{c}\text { Pearson } \\
\text { Correlation } \\
\text { Sig. (2-tailed) } \\
\mathrm{N}\end{array}$ & $\begin{array}{r}1 \\
396\end{array}$ & & & & \\
\hline $\begin{array}{l}\text { Taxpayers' } \\
\text { knowledge }\end{array}$ & $\begin{array}{c}\text { Pearson } \\
\text { Correlation } \\
\text { Sig. (2-tailed) } \\
\mathrm{N}\end{array}$ & $\begin{array}{r}.596^{* *} \\
.000 \\
396\end{array}$ & $\begin{array}{r}1 \\
396 \\
\end{array}$ & & & \\
\hline $\begin{array}{l}\text { Taxpayers' } \\
\text { awareness }\end{array}$ & $\begin{array}{c}\text { Pearson } \\
\text { Correlation } \\
\text { Sig. (2-tailed) } \\
\text { N }\end{array}$ & $\begin{array}{r}.619^{* *} \\
.000 \\
396\end{array}$ & $\begin{array}{c}.612^{* *} \\
.000 \\
396\end{array}$ & $\begin{array}{r}1 \\
396\end{array}$ & & \\
\hline Tax socialization & $\begin{array}{c}\text { Pearson } \\
\text { Correlation } \\
\text { Sig. (2-tailed) } \\
\mathrm{N} \\
\end{array}$ & $\begin{array}{r}.612^{* *} \\
.000 \\
396 \\
\end{array}$ & $\begin{array}{r}.876^{* *} \\
.000 \\
396 \\
\end{array}$ & $\begin{array}{r}.728^{* *} \\
.000 \\
396 \\
\end{array}$ & $\begin{array}{r}1 \\
396 \\
\end{array}$ & \\
\hline $\begin{array}{l}\text { Taxpayers' } \\
\text { compliance }\end{array}$ & $\begin{array}{c}\text { Pearson } \\
\text { Correlation } \\
\text { Sig. (2-tailed) } \\
\mathrm{N}\end{array}$ & $\begin{array}{r}.587^{* *} \\
.000 \\
396\end{array}$ & $\begin{array}{r}.576^{* *} \\
.000 \\
396\end{array}$ & $\begin{array}{r}.653^{* *} \\
.000 \\
396\end{array}$ & $\begin{array}{r}.606^{* *} \\
.000 \\
396\end{array}$ & $\begin{array}{r}1 \\
396\end{array}$ \\
\hline
\end{tabular}

**. Correlation is significant at the 0.01 level (2-tailed). 
The output of correlation above explains the value of the correlation coefficient and the significant value between each independent variable and the dependent variable. The entire correlation coefficient values are close to 1 , this can be concluded that the relationship between each independent variables with the dependent variable are close. Besides, the entire output of significance values (Sig. 2-tailed) are 0.000 . Significance value $<0.05$ then Ho were refused. Therefore, this can be concluded that there is a relationship between each independent variables on dependent variable. Moreover, each relationship are positive because the correlations value are positive.

\section{Determination Coefficient Test $\left(\mathbf{R}^{2}\right)$}

The determination coefficient is indicated by $\mathrm{R}^{2}$. The numbers will be converted into percentages, this means the percentage contribution of the influence of independent variables on the dependent variable. It can be concluded that the coefficient of determination is used to measure how far the model's ability to explain dependent variations. The results of the coefficient of determination in this study are as follows:

Table 3 Determination Coefficient Test $\left(R^{2}\right)$

\begin{tabular}{|c|c|c|c|c|}
\hline \multicolumn{5}{|c|}{ Model Summary } \\
\hline $\begin{array}{c}\text { Mode } \\
1\end{array}$ & $\mathrm{R}$ & R Square & $\begin{array}{c}\text { Adjusted R } \\
\text { Square }\end{array}$ & $\begin{array}{c}\text { Std. Error of } \\
\text { the Estimate }\end{array}$ \\
\hline 1 & $.710^{\mathrm{a}}$ & .503 & .498 & .487 \\
\hline \multicolumn{5}{|c|}{} \\
a. Predictors: (Constant), Tax socialization, Attitude of \\
taxpayers', Taxpayers' awareness, Taxpayers' knowledge
\end{tabular}

Based on the table above, the result of the $\mathrm{R}^{2}$ value is 0.503 . Then the percentage of influence of the entire independent variables on the dependent variable is $50.3 \%$, this means that the independent variable used in this study is $50.3 \%$ and the rest is influenced by other variables.

\section{Hypothesis-testing}

Simultaneous Hypothesis testing consists of two parts namely, F-test and t-test. F-test aims to find out the influence of the entire independent variables together on taxpayers' compliance. On the other hand, t-test aims to find out the influence of each independent variables on taxpayers' compliance.

\section{Simultaneous Significant Test (F-Test)}

Simultaneous Significant Test (Test F) aims to determine whether regional wealth, debt financing, total assets, and the total number of Local Government Apparatus together influence the Level of disclosure of local government financial reports. This $\mathrm{F}$ test is carried out by comparing the calculated $\mathrm{F}$ results with $\mathrm{F}$ according to the table. Based on the results of data processing in the table below, it can be seen that the $\mathrm{F}$ test results are as follows:

Table 4 F-test

\begin{tabular}{|c|c|c|c|c|c|c|}
\hline \multicolumn{7}{|c|}{ ANOVA $^{\mathrm{a}}$} \\
\hline \multicolumn{2}{|c|}{ Model } & $\begin{array}{c}\text { Sum of } \\
\text { Squares }\end{array}$ & $\mathrm{df}$ & $\begin{array}{l}\text { Mean } \\
\text { Square }\end{array}$ & $\mathrm{F}$ & Sig. \\
\hline 1 & $\begin{array}{c}\text { Regress } \\
\text { ion }\end{array}$ & 94.015 & 4 & 23.504 & $\begin{array}{r}99.09 \\
4\end{array}$ & $.000^{\mathrm{b}}$ \\
\hline & $\begin{array}{c}\text { Residua } \\
1\end{array}$ & 92.740 & 391 & .237 & & \\
\hline & Total & 186.755 & 395 & & & \\
\hline
\end{tabular}

a. Dependent Variable: Taxpayers' compliance

b. Predictors: (Constant), Tax socialization, Attitude of taxpayers', Taxpayers' awareness, Taxpayers' knowledge

Based on the result above, this is known that the $F_{\text {count }}$ is 99.094 with a significance level of 0.000 . Furthermore, the calculated $F_{\text {count }}$ compared with the value of $F_{\text {table }}$ where the number of independent variables $(\mathrm{k})=4$ and the number of samples $(\mathrm{n})=396$, then obtained df1 (number of variables-1) $=3$ and $\mathrm{df} 2$ (nk-1) or (396-4-1) = 391 ( $\mathrm{n}$ is the amount of data and $\mathrm{k}$ is the number of independent variables). This shows that the value of $F_{\text {count }}$ has a value greater than $F_{\text {table }}$ (99.094> 2.63). Furthermore, the significant value is smaller than the significance level $\alpha=5 \%$ which is $0,000<0.05$, therefore this can be concluded that simultaneously the independent variables namely attitude of taxpayers, taxpayers' knowledge, taxpayers' awareness, and tax socialization together have a significant influence on taxpayers' compliance.

\section{Simultaneous Significant Test (t-Test)}

T-test is a significant test to determine the effect of variables $\mathrm{X}_{1}, \mathrm{X}_{2}, \mathrm{X}_{3}$ and $\mathrm{X}_{4}$ on $\mathrm{Y}$ partially. This has a significant effect or not. To find out whether this is significant or not, the $t_{\text {count }}$ will be compared with $t_{\text {table }}$. $t_{\text {table }}$ was sought at a significant $0.05 / 2=0.025$ (2-side test) with degrees of freedom $\mathrm{df}=\mathrm{n}-\mathrm{k}-1$. If the calculated $t$ value is greater than $t_{\text {table }}$ and significantly smaller than the significant level $<\alpha=5 \%$, then the variable has an influence on the dependent variable. Based on the above data description, the results of the t-test management are as follows: 
Table 5 t-test

\begin{tabular}{|c|c|c|c|c|c|c|}
\hline \multicolumn{7}{|c|}{ Coefficients $^{\mathrm{a}}$} \\
\hline & \multirow[t]{2}{*}{ Model } & \multicolumn{2}{|c|}{$\begin{array}{l}\text { Unstandardized } \\
\text { Coefficients }\end{array}$} & \multirow{2}{*}{$\begin{array}{c}\text { Standardized } \\
\text { Coefficients }\end{array}$} & \multirow[t]{2}{*}{$\mathbf{t}$} & \multirow[t]{2}{*}{ Sig. } \\
\hline & & $\mathrm{B}$ & Std. Error & & & \\
\hline \multirow{5}{*}{1} & (Constant) & .500 & .187 & & 2.679 & .008 \\
\hline & Attitude of taxpayers' & .249 & .054 & .224 & 4.614 & .000 \\
\hline & Taxpayers' knowledge & .190 & .081 & .177 & 2.336 & .020 \\
\hline & Taxpayers' awareness & .388 & .057 & .376 & 6.799 & .000 \\
\hline & Tax socialization & .044 & .092 & .041 & .477 & .633 \\
\hline & pendent Variable: Taxp & compli & & & & \\
\hline
\end{tabular}

Based on the results above, this is known that this study uses a sample $(\mathrm{n})=396$ and the number of independent variables $(\mathrm{k})=4$ which is $(396-4-1=391)$, then the $t_{\text {table }}$ in this study is 1.966 . Based on the partial test results in the table above, this can be concluded as follows:

H1: Attitude of taxpayers have an influence on taxpayers' compliance during the Covid-19.

Variable attitude of taxpayers that have $t_{\text {count }}$ $4.614<\mathrm{t}_{\text {table }} 1.966$ and a significant value of $0.000<0.05 . \mathrm{H}_{\mathrm{o}}$ was refused and $\mathrm{H}_{1}$ was accepted. Therefore, this can be concluded that partially the independent variable attitude of taxpayers' have effect and no significant on the dependent variable, namely taxpayers' compliance.

The results of this study are in line with research from (Yustikasari et al., 2020), (Aruan et al., 2017), (Mintje, 2016), and (Budhiartama \& Jati, 2016) indicating that taxpayer attitudes influence taxpayers' compliance. Meanwhile, it is different from the results of the research of (Wijaya \& Sari, 2020) and (Dewi \& Putra, 2019) which state that the attitude of the taxpayers' does not affect taxpayers' compliance. The attitude of taxpayers' towards MSMEs income tax will contribute to the State's opinion from the tax sector. The attitude of small and medium entrepreneurs in paying tax compliance is expected to give good income for income tax, especially among MSMEs. The adoption of the self-assessment system carries the mission and consequences of changing people's attitudes (awareness) to pay taxes voluntarily. Moreover, this shows that there is no difference in the attitude of MSMEs that take into account financial conditions in fulfilling their tax obligations and the risks that will arise due to not paying taxes during the Covid-19 pandemic. Although the government in this case the Directorate General of Taxes also provides stimulants for MSME players, with PMK No.86 / PMK.03 / 2020, as the abolition of PMK No.44 / PMK.03 / 2020, this rule is an amendment to PMK No. 23 /PMK.03/2020 regarding tax incentives for taxpayers' affected by the coronavirus outbreak.

H2: Taxpayers' knowledge has an influence on taxpayers' compliance during the Covid-19.
Variable taxpayers' knowledge that has $t_{\text {count }}$ $2.336>t_{\text {table }} 1.966$ and a significant value of $0.020<0.05 . \mathrm{H}_{\mathrm{o}}$ was refused and $\mathrm{H}_{2}$ was accepted. Therefore, this can be concluded that partially the independent variable taxpayers' knowledge has an effect and significant on the dependent variable, namely taxpayers' compliance.

The results of this test mean that the more adequate the taxpayers' knowledge regarding taxation, the level of taxpayers' compliance will increase. These findings support the theory of planned behavior and the theory of compliance, where when a person is given sufficient knowledge about taxation, that person will know and have obedient behavior (Handayani \& Woro Damayanti, 2018). The results of previous research conducted by (Dodik et al., 2020) and (Susilawati \& Budiartha, 2019) show that tax knowledge has a positive and significant effect on taxpayer compliance. This research is not following the research conducted by (Markhumah, 2019) which states that knowledge of taxation does not affect taxpayer compliance. As it is known that the level of taxpayers' compliance who are sampled is still not maximal, therefore a solution is needed to increase compliance. Concerning taxpayers' knowledge based on the description of statistical data, it can be seen that the public's perception of the currently applied tax rate is considered inappropriate, therefore it is necessary to hold ongoing socialization and education to increase taxpayers' knowledge.

H3: Taxpayers' awareness has an influence on taxpayers' compliance during the Covid-19.

Variable taxpayers' awareness that has $t_{\text {count }}$ $6.799>\mathrm{t}_{\text {table }} 1.966$ and a significant value of $0.000<$ $0.05 . \mathrm{H}_{\mathrm{o}}$ was refused and $\mathrm{H}_{3}$ was accepted. Therefore, this can be concluded that partially the independent variable taxpayers' awareness has an effect and significant on the dependent variable, namely taxpayers' compliance.

The results of this test mean that the more aware taxpayers are of their tax obligations, the level of taxpayer compliance will increase. These findings support the theory of planned behavior and the theory of compliance, where when someone has a high 
awareness of their obligations as a taxpayer, that person will obey and obey in carrying out their tax obligations. The results of previous research conducted by (Dodik et al., 2020) and (Nurkhin et al., 2018) show that taxpayers' awareness has a significant and positive effect on taxpayer compliance. This study is not following the research conducted by (Nugroho et al., 2016) which states that taxpayer awareness does not have a partial effect on taxpayer compliance. As it is known that the level of compliance of taxpayers who are sampled is still not maximal, therefore a solution is needed to increase compliance. Concerning taxpayer awareness, based on the description of statistical data it can be seen that the perception of public trust about taxes is still low, therefore it is necessary to hold tax socialization and transparency to increase taxpayer awareness.

H4: Tax socialization has an influence on taxpayers' compliance during the Covid-19.

Variable tax socialization that has $t_{\text {count }} 0.477<$ $t_{\text {table }} 1.966$ and a significant value of $0.633>0.05 . \mathrm{H}_{\mathrm{o}}$ was accepted and $\mathrm{H}_{4}$ was refused. Therefore, this can be concluded that partially the independent variable tax socialization has no effect and significant on the dependent variable, namely taxpayers' compliance.

The result of this test means that the socialization of taxation does not help increase the knowledge of taxpayers about the importance of paying taxes so that the taxpayers comply. Although most taxpayers are aware of taxation socialization, either directly or indirectly, and have followed the socialization and obtained tax information through this socialization. However, good tax socialization may not necessarily affect the compliance of MSME taxpayers in Palembang. This is because taxpayers cannot properly understand the taxation material or information submitted by individuals from the Directorate General of Taxation and taxation material or information is not detailed. Taxpayers' lack of understanding of the taxation material or information submitted could be due to the large number of Taxpayers who participated in the direct socialization so that the taxation material or information submitted could not be conveyed thoroughly to Taxpayers in other words, the socialization did not work effectively. For indirect socialization, it can be caused by the indirect socialization activities are relatively short and the taxation material and information conveyed tends to be general (not detailed) and it is possible that the media used is not suitable with the study or is not appropriate for the audience. The results of this study are in line with research from (Wijaya \& Sari, 2020), (Setyaningrum, 2017), and (Winerungan, 2013) which states that taxation socialization does not affect taxpayer compliance, while different from the results of (I. K. Sari \& Saryadi, 2019), (Boediono et al., 2018), (Hafiz \& Saryadi, 2018), (Wardani \& Wati,
2018), and (Lubis, 2017) state that tax socialization affects taxpayers' compliance.

\section{CONCLUSION}

The Covid-19 Pandemic has had a significant impact, especially on MSMEs in Palembang City. With many MSMEs experiencing reduced income, it makes taxpayers disobedient in paying taxes. Therefore, the purpose of this research is to determine the effect of the Covid-19 Pandemic on taxpayers' compliance in Palembang, Indonesia. There are results from this study, namely the variables that affect taxpayers' compliance in this study are the attitude of taxpayers, taxpayers' knowledge, and taxpayers' awareness. First, there is no difference in the attitude of taxpayers' (MSMEs) that take into account financial conditions in fulfilling their tax obligations and the risks that will arise due to not paying taxes during the Covid-19 pandemic. Second, the more adequate the taxpayers' knowledge regarding taxation, the level of taxpayers' compliance will increase. Therefore, this finding supports the theory of planned behaviour and the theory of compliance, where when a person is given sufficient knowledge about taxation, that person will know and have obedient behaviour. Third, the more aware taxpayers are of their tax obligations, the level of taxpayer compliance will increase. This finding also supports the theory of planned behaviour and the theory of compliance, where when someone has a high awareness of their obligations as a taxpayer, that person will obey and obey in carrying out their tax obligations. However, tax socialization does not affect taxpayers' compliance. The socialization delivered by individuals from the Directorate General of Taxes must be detailed, therefore the socialization can be effective and easier for taxpayers to understand the flow and policies of the taxation regulations for MSMEs in Palembang City. Furthermore, considering that there are many populations of MSMEs, it will greatly assist the country's economy by obediently paying taxes, especially during the Covid-19 Pandemic. With this research, the government especially the directorate general of taxation can maximize taxpayers' compliance, especially among MSMEs. Besides, this research can also increase the country's income, especially during the Covid-19 pandemic. Also, there are limitations from this study, namely, when distributing questionnaires using social media, researchers did not divide MSMEs based on subsections the type of taxpayer's business. Moreover, this study only used four variables that have a relationship with taxpayers' compliance. Therefore, in the future, the further researcher should divide MSME based on the taxpayer's business type to get more optimal results and add several variables that not included in this study such as tax penalties and selfassessment systems. 


\section{REFERENCES}

Adnyana, I. G. A., \& Jati, I. K. (2018). Effect of Tax Sanctions, Use of e-SPT, and Quality of Fiscal Services on Individual Taxpayer Compliance. EJurnal Akuntansi, 25(3), 2129-2154. https://doi.org/10.24843/EJA.2018.v25.i03.p19

Ajzen, I. (2005). The Influence of Attitudes on Behavior. In The Handbook of Attitudes (pp. 173-222). http://books.google.com/books?hl=en\&lr=\&id=qoJ5 AgAAQBAJ\&oi=fnd\&pg=PA173\&dq=The+Influen ce + of + Attitudes + on+Behavior\&ots $=I 3 \mathrm{vmnYWDce}$ \&sig=1ASAmilgqxpMyNlnszyUROK82Fg\%0Ahttp ://books.google.com/books?hl=en\&lr=\&id=qoJ5Ag AAQBAJ\&oi=fnd\&pg=PA173\&dq=The + influence + of +

Aruan, R., Sujana, E., Luh, N., \& Erni, G. (2017). The Influence of Taxpayer Attitudes, Taxpayer Morals and Willingness to Pay Individual Taxes at the Tax Office (KPP) Pratama Gianyar. E-Journal S1 Ak Universitas Pendidikan Ganesha, 8(2), 1-10.

Bayu, D. J. (2021). UNDP: The income of 77\% of MSMEs has decreased due to the Corona Pandemic. Databoks.

https://databoks.katadata.co.id/datapublish/2021/01/ 29/undp-pendapatan-77-umkm-berkurang-akibatpandemi-corona

Boediono, G. T., Sitawati, R., \& Harjanto, S. (2018). Analysis of the Influence of Taxation Socialization on Taxpayer Compliance with Awareness as a Mediation Variable. Jurnal Penelitan Ekonomi Dan Bisnis, 3(1), 22-37. https://doi.org/10.33633/jpeb.v3i1.2286

Brainyyah, M. Q. (2013). The Effect Of Fairness, Tax Knowledge, And Tax Complexity On Tax Compliance: The Case Of SME Entrepreneurs' Taxpayers In Malang. Jurnal Ilmiah Mahasiswa Feb Universitas Brawijaya, 1(2), 1-17.

Budhiartama, I. G. P., \& Jati, I. K. (2016). The Effect Of Attitude, Taxpayer Awareness And Tax Knowledge On Compliance With Earth And Building Taxes. EJurnal Akuntansi Universitas Udayana, 15(2), 15101535.

Cahyani, L. P. G., \& Noviari, N. (2019). The Effect of Tax Rates, Tax Understanding, and Tax Sanctions on SME Taxpayer Compliance. E-Jurnal Akuntansi, 26(3), $1885-1911$. https://doi.org/10.24843/EJA.2019.v26.i03.p08

Christiani, E. V. (2016). Factors Affecting Tax Avoidance Actions in Semarang City. Semarang University.

Department of Cooperatives and MSMEs. (2019). http://www.depkop.go.id/

Dewi, Z., \& Putra, U. Y. (2019). The Influence of Taxpayer Attitudes, Fiscal Services, and Tax Socialization on Taxpayer Compliance in Paying Taxes. Jurnal Riset Akuntansi, 9, 216-224. http://dx.doi.org/10.35448/jrat.v9i2.4310

Directorate General of Taxes 2020. (2020).

Dodik, A., Putu, W. A. G. A., \& Asri, D. P. I. G. A. M. (2020). Influence of justice, culture and love of money towards ethical perception on tax evasion with gender as moderating variable. Journal of Money Laundering Control, 23(1), 245-266. https://doi.org/10.1108/JMLC-06-2019-0047

Ermawati, N. (2018). The Effect of Religiosity, Taxpayer Awareness and Knowledge of Taxation on Taxpayer Compliance. Jurnal STIE Semarang, 10, 106-122. 10.33747/stiesmg.v10i1.89

Faizin, M. R., K., \& Ruhana, I. (2016). The Influence of Socialization, Understanding, and Awareness of Tax Procedures on Taxpayer Compliance (Studies on Individual Taxpayers of Rural and Urban Land and Building Taxes in Mojoranu Village, Bojonegoro Regency). Jurnal Mahasiswa Perpajakan, 9, 1-9.

Ghouri, A. M., Khan, N. R., \& Abdul Kareem, O. B. (2016). Improving Employees Behavior through Extension in Theory of Planned Behavior: A Theoretical Perspective for SMEs. E-Jurnal Akuntansi, 26, 18851911.

https://doi.org/10.24843/EJA.2019.v26.i03.p08

Hafiz, M., \& Saryadi. (2018). The Influence of Taxpayer Socialization on Taxpayer Compliance through Understanding Taxpayers as an Intervening Variable (Empirical Study of Tax Amnesty Policy at Umkm at Kpp Pratama Semarang Tengah Dua). Jurnal Ilmu Administrasi Bisnis, 7(3), 467-475.

Handayani, O., \& Woro Damayanti, T. (2018). Determinants of Individual Taxpayers' Compliance in Indonesia: A Meta-Analysis. The Indonesian Journal of Accounting Research, 21(1), 1-22. https://doi.org/10.33312/ijar.332

Handke, L., \& Barthauer, L. (2019). The Psychology of Interpersonal Relations, In Schlüsselwerke der Netzwerkforschung. Springer VS, Wiesbaden. https://doi.org/10.1007/978-3-658-21742-6 59

Hardiningsih, P., \& Yulianawati, N. (2011). Factors Affecting The Will To Pay Taxes. Dinamika Keuangan Dan Perbankan, 3(1), 126-142.

Hui, D. S., E., I. A., Madani, T. A., Ntoumi, F., \& Kock, R., Dar, O. (2020). The continuing 2019-nCoV epidemic threat of novel coronaviruses to global health - The latest 2019 novel coronavirus outbreak in Wuhan, China. International Journal of Infectious Diseases, 91, 264-266. 10.1016 / j.ijid.2020.01.009

Ilmiyah, S. (2020). Surotul Ilmiyah - PBNU's Efforts to Prevent the Spread of COVID-19. Jurnal Ilmu Pendidikan, 2(1), 28-37.

Kamil, N. I. (2015). The effect of taxpayer awareness, knowledge, tax penalties and tax authorities services on the tax complience: Survey on the individual taxpayer at Jabodetabek \& Bandung). Research Journal of Finance and AccountingOnline), 6(2), 104-112.

https://www.iiste.org/Journals/index.php/RJFA/artic le/view/19180/19738

Kline, R. B. (2011). Principles and Pratice of Structural Equation Modeling (Third Ed.). Guilford Press.

Koshle, H., \& Kaur, R. B. R. (2020). Breakdown of Business and Workers in India, Impact of Corona Virus. $\quad S S R N, \quad 2, \quad 1-9$. http://dx.doi.org/10.2139/ssrn.355754\%0A4

Laraswati, A. W. (2020). Surotul Ilmiyah - PBNU's Efforts to Prevent the Spread of COVID-19. Jurnal Penelitian Politik, 17(2), 255-307. http://ejournal.politik.lipi.go.id/index.php/jpp/article /view/883

Lubis, R. H. S. M. S. (2017). The Effect Of Taxation Service Quality, And Taxation Sanctions On Taxpayer Compliance At KPP Pratama Medan Belawan. Jurnal Akuntansi Dan Bisnis, 3(1), 61-71. https://doi.org/10.31289/jab.v3i1.425

Markhumah, U. (2019). The Influence of Firmness of Tax Sanctions, Tax Knowledge, Tax Amnesty, Fiscal Services, Tax Reforms on Taxpayer Unity (Empirical 
Study of Corporate Taxpayers at KPP Pratama Surakarta). The 9th University Research Colliqium, 9(3), 191-198.

Marsudi, \& P, R. L. (2020). International Cooperation to Mitigate COVID-19. https://kemlu.go.id/

Mintje, M. S. (2016). Effect Of Attitude,Awareness, And Knowledge Against Taxpayer Compliance Individual Owner Of ( SMES ) In Having ( TIN ). JURNAL EMBA, 4(1), 1031-1043. https://doi.org/10.35794/emba.v4i1.11851

Mohammed, M. N., Hazairin, N. A., Al-Zubaid, S., A.K, S., \& Mustapha, S., \& Yusuf, E. (2020). Toward A Novel Design For Coronavirus Detection And Diagnosis System Using Iot Based Drone Technology. International Journal of Psychosocial Rehabilitation, 24(7), 2287-2295. https://doi.org/10.37200/IJPR/V24I7/PR270220

Mohammed, M. N., Hazairin, N. A., Syamsudin, H., AlZubaidi, S., A.K., S., Mustapha, S., \&, \& Yusuf, E. (2020). 2019 Novel Coronavirus Disease ( Covid-19 ): Detection and Diagnosis System Using IoT Based Smart Glasses. International Journal of Advanced Science and Technology, April.

Mohammed, M. N., Syamsudin, H., Al-Zubaidi, S., A.K, S., Ramli, R., \&, \& Yusuf, E. (2020). Novel Covid-19 Detection And Diagnosis System Using Iot Based Smart Helmet. International Journal of Psychosocial Rehabilitation, 24(7), 2296-2303. https://doi.org/10.37200/IJPR/V24I7/PR270221

Noviyanti, \& Ferdous, S. M. A. (2020). The Effect of Tax Sanctions, Self-Assessment System, E-Commerce, and AEoI toward Tax Avoidance of Online Business in Indonesia. Psychology and Education Journal, 57(9), 2000-2008. https://doi.org/10.17762/pae.v57i9.561

Nugroho, A., Andini, R., \& Raharjo, K. (2016). The Influence of Taxpayer Awareness and Taxpayer Knowledge of Taxpayers on Taxpayer Compliance in Paying Income Taxes (case study at KPP Semarang Candi). Journal Of Accounting, 2(2), 1-8.

Nurkhin, A., Novanty, I., Muhsin, M., \& Sumiadji, S. (2018). The Influence of Tax Understanding, Tax Awareness and Tax Amnesty toward Taxpayer Compliance. Jurnal Keuangan Dan Perbankan, 22(2), 240-255.

Perdana, E. S., \& Dwirandra, A. A. N. . (2020). The Influence of Taxpayer Awareness, Tax Knowledge, and Tax Sanctions on SME Taxpayer Compliance. EJurnal Akuntansi, 30(6), 1458. https://doi.org/10.24843/eja.2020.v30.i06.p09

Pramandari, N. M. H., Yasa, N. P., \& Herawati, N. T. (2018). Uncovering Perceptions of Micro, Small and Medium Enterprises (Umkm) About the Implementation of Government Regulation Number 23 of 2018. JIMAT (Jurnal Ilmiah Mahasiswa Akuntansi), 9(1), 111-120.

Rosita, R. (2020). The Influence of the Covid-19 Pandemic on Umkm in Indonesia. Jurnal Lentera Bisnis, 9(2), 109. https://doi.org/10.34127/jrlab.v9i2.380

Sari, A. P., \& Wirakusuma, M. G. (2018). Perception of Tax Amnesty as a Moderator of the Influence of Taxpayer Awareness and Tax Sanctions on WPOP Compliance. E-Jurnal Akuntansi, 22(1), 464-491. https://doi.org/10.24843/EJA.2018.v22.i01.p18

Sari, I. K., \& Saryadi. (2019). The Influence of Taxation Dissemination and Knowledge of Taxation on Taxpayer Compliance through Taxpayer Awareness as an Intervening Variable (Case Study of Registered MSMEs in KPP Pratama East Semarang). Jurnal Ilmu Administrasi Bisnis, 8(3), 126-135.

Sekaran, U., \& Bougie, R. (2016). Research Methods For Business. John Wiley \& Son Ltd.

Sentanu, I. N. W., \& Setiawan, P. E. (2016). Effect Of Service Quality, Moral Obligations And Taxation Sanctions On Hotel Tax Compliance. E-Jurnal Akuntansi, 16(1), 306-332.

Setyaningrum, T. . (2017). The Influence of Awareness Mediation and Awareness of the Compliance of Land and Building Taxpayers in Pekalongan City. Universitas Dian Nuswantoro.

Subekti, S. . (2016). Factors Affecting Taxpayer Compliance with Risk Preference as Moderating Variables (Case Study of Hotel Taxpayers in DIY). Jurnal Publikasi, 1-21.

Sudrajat, A., \& Ompusunggu., A. P. (2015). Utilization of Information technology, Tax Dissemination, Tax Knowledge, and Tax Compliance. Jurnal Riset Akuntansi Dan Perpajakan, 2(2), 193-202.

Sufiah. (2017). The Influence of Internal Factors and External Factors on Individual Taxpayer Compliance in Surabaya City. Jurnal Akuntansi Akunesa, 5(3), 125.

Sulistiyani, R., \& Harwiki, W. (2016). How SMEs Build Innovation Capability Based on Knowledge Sharing Behavior? Phenomenological Approach. Procedia Social and Behavioral Sciences.

Susilawati, K. E., \& Budiartha, K. (2019). The influence of taxpayer awareness, tax knowledge, tax sanctions and public service accountability on motor vehicle taxpayer compliance. E-Jurnal Akuntansi Universitas Udayana, 4(2), 345-357. https://doi.org/ISSN: 2302-8556

Susyanti, J., \& Anwar, S. A. (2020). Effect Of Taxpayer Attitude, Taxpayer Awareness Toward Tax Compliance In The Time Of Covid-19. Sebatik, $1(10)$, 171-177. https://doi.org/10.30588/jmp.v3i1.84

Utami, T. D., \& Kardinal. (2012). The Effect of Taxpayer Awareness and Tax Sanctions on Individual Taxpayer Compliance at the Palembang Seberang Ulu Primary Tax Service Office. Palembang: STIE MDP.

Utomo, B. A. W. (2011). Attitudes, Taxpayer Awareness and Tax Knowledge Against Taxpayer Compliance in Paying Land and Building Taxes in Pamulang District, South Tangerang City [UIN Syarif Hidayatullah]. http://repository.uinjkt.ac.id/dspace/handle/1234567 $89 / 1462$

Wahyudi, T., \& Intrada, B. (2019). The Influence of Personal Taxpayer Attitudes Related to the Implementation of Administrative Sanctions, Account Representative Services and Ability to Pay Tax Amnesty Ransom to the Compliance of Individual Taxpayers in Palembang City, Indonesia. Journal of Accounting Finance and Auditing Studies (JAFAS), 5(2), 38-56. https://doi.org/10.32602/jafas.2019.19

Wardani, D. K., \& Wati, E. (2018). The Effect Of Taxation Socialization On Taxpayer Compliance With Taxation Knowledge As Intervening Variables (Study On Individual Taxpayers At KPP Pratama Kebumen). Nominal, Barometer Riset Akuntansi Dan Manajemen,

$7(1)$. 
https://doi.org/10.21831/nominal.v7i1.19358

Widagsono, S. (2017). Knowledge of Taxation, Sanctions and Religiosity to Taxpayer Compliance (KPP Pratama Kepanjen Case Study). Universitas Islam Negeri Maulana Malik Ibrahim.

Widowati, R. (2015). Taxpayer Compliance through Tax Socialization, Tax Sanctions, Tax Knowledge and Fiscal Services. Jurnal Akuntansi Universitas Dian Nuswantoro Semarang, 1(2), 1-16.

Wijaya, I., \& Sari, D. K. (2020). Individual Taxpayer Compliance in terms of Ease of E-filing System Implementation and Tax Knowledge. Jurnal Online Insan Akuntan, 5(1), 1-12. ttps://doi.org/10.51211/joia.v5i1.1314

Winerungan, O. L. (2013). Tax Socialization, Fiscal Service, Tax Sanctions on Individual Taxpayer Compliance at KPP Manado and KPP Bitung. 1(3), 9-37.

Yustikasari, M. Y., Susyanti, J., \& Hufron, M. (2020). The Influence of Taxpayer Attitudes, Taxpayer Awareness, and Knowledge of Taxation on Individual Taxpayer Compliance with Creative Economy Actors in the Fashion Sub-Sector in Batu City. 82-94.

Yusuf, E., Syamsudin, H., N., M. M., Al-Zubaidie, S., \& Sairah, A. K. (2020). 2019 Novel Coronavirus Disease (Covid-19): Thermal Imaging System for Covid-19 Symptom Detection Using Iot Technology. Revista Argentina de Clínica Psicológica, 29(5), 234. https://doi.org/10.24205/03276716.2020.1025 